\title{
ОСОБЛИВОСТІ ПСИХОЛОГІЧНИХ РОЗЛАДІВ У ХВОРИХ З ІШЕМІЧНОЮ ХВОРОБОЮ СЕРЦЯ ПІСЛЯ ХІРУРГІЧНОЇ РЕВАСКУЛЯРИЗАЦІЇ МІОКАРДА НА РІЗНИХ ЕТАПАХ РЕАБІЛІТАЦІї
}

\section{ДУ «Український науково-дослідний інститут медичної реабілітації та курортології мОз України»}

РЕЗЮМЕ. Стаття присвячена вивченню особливостей психологічного стану хворих з ішемічною хворобою серця після хірургічної реваскуляризації міокарда (ХРМ) в залежності від терміну надходження на реабілітацію.

Матеріал і методи. Було обстежено 65 пацієнтів після аортокоронарного шунтування (АКШ) (17 пацієнтів через 7 діб після оперативного втручаннята 48-через 1-2 місяці). Для оцінки психологічного станувикористовували шкалу HADS і шкалу тривожності Спілбергера, якість життя оцінювали за шкалою SF-36.

Результати. Виявлено вірогідне зниження якості життя у пацієнтів, які поступали на реабілітацію через 1-2 місяці та не отримували раннього відновлювального лікування. При оцінці тривоги та депресії за шкалою HADS були виявлені субклінічні тривожно-депресивні розлади у 43,9 \% пацієнтів при ранньому надходженні на реабілітацію та у 53,5 \% - при пізньому. Зниження якості життя за рахунок рольового функціонування більш виразним було у пацієнтів, які не отримували ранньої реабілітації $(p \leq 0,05)$.

КЛючОВІ СлОВА: ішемічна хвороба серця; хірургічна реваскуляризація міокарда; етапна реабілітація; якість життя; психологічні розлади.

Вступ. Широке застосування хірургічних методів лікування ішемічної хвороби серця (IXC) дозволило знизити не тільки смертність, а й частоту нападів стенокардії, що дозволило більшості пацієнтів повернутися до своєї професійної діяльності. Незважаючи на вдосконалення хірургічної техніки аортокоронарного шунтування (АКШ) у хворих в післяопераційному періоді зберігаються явища дезадаптації кардіореспіраторної системи, найбільш виражені в ранній термін, які проявляються кардіалгіями, порушеннями біоелектричної активності серця і аритміями, зниженням скорочувальної здатності міокарда, коронарного, міокардіального і аеробного резервів організму, розвитком запальних і рубцевих змін в органах і тканинах грудної клітки $[1,2,6]$.

Зазначені явища обумовлені тяжкістю вихідного стану хворих і певним посиленням його під час наркозу, оперативного втручання, проведеного з підключенням апарату штучного кровообігу і поєднаного з відомою внутрішньоопераційною ішемією міокарда. Внаслідок наявності обширної травми грудної клітки, яка $\epsilon$ джерелом больового синдрому, і післяопераційної гіпоксії, майже у всіх пацієнтів наявні функціональні порушення центральної нервової системи: ці хворі швидко втомлюються, дратівливі, надмірно фіксовані на своєму стані, тривожні, погано сплять, скаржаться на головні болі і запаморочення [7].

Хірургічне лікування IXC та застосування інтервенційних технологій не усуває основних причин цього захворювання. Операція шунтування коронарних судин, як і ендоваскулярне протезування, не усуває супутніх хвороб, а іноді призво- дить до їх загострення. Основні фактори ризику ускладнень і подальшого прогресування хвороби не зменшують своєї значущості і після оперативного втручання $[3,4]$. Тому пряму і непряму реваскуляризацію міокарда потрібно розглядати тільки як паліативний метод лікування IXC, який повинен входити в комплекс етіопатогенетичної терапії, що починається з підготовки до кардіохірургічної допомоги і безпосередньо після нього триває у вигляді спеціалізованої медичної реабілітації [5]. Клінічна ефективність хірургічної реваскуляризації міокарда (ХРМ) в значній мірі визначається реабілітаційною програмою саме на етапі спеціалізованої медичної реабілітації, спрямованої на закріплення результатів хірургічного та консервативного лікування, запобігання виникненню ускладнень і повторних судинних катастроф, фізичну і медико-психологічну реадаптацію хворих на IXC після XРM [6].

Незважаючи на те, що АКШ і ЕВП спрямовані на відновлення працездатності та поліпшення якості життя людини, ці кардіохірургічні втручання самі $\epsilon$ для хворого значним стресом і дезадаптивним фактором. При відсутності адекватного післяопераційного і подальшого відновного лікування це призводить до того, що більшість пацієнтів працездатного віку, які перенесли ХРМ, не можуть своєчасно повернутися до повноцінної праці. Тому медична реабілітація хворих на ішемічну хворобу серця після операції $\epsilon$ важливою проблемою відновної медицини, що має не тільки медичне, а й велике соціальне значення [8].

Ефективність будь-яких методів реваскуляризації міокарда в результаті визначається не 
Огляди літератури, оригінальні дослідження, погляд на проблему

тільки ступенем відновлення коронарного кровотоку, а й успіхом вторинної профілактики, лікуванням супутніх захворювань, боротьбою з факторами ризику серцево-судинних захворювань, поліпшенням якості життя, темпом повернення до повноцінної трудової діяльності, частотою ускладнень і тривалістю життя.

Мета роботи-вивчити особливості психологічного стану та якості життя хворих на ішемічну хворобу серця після ХРМ при надходженні на реабілітацію в різні строки після оперативного втручання.

Матеріал і методи дослідження. Під нашим спостереженням в лікувально-оздоровчому комплексі «Біла акація» було 65 пацієнтів у віці $(58,7 \pm 8,9)$ років після аортокоронарного шунтування (АКШ), які отримували стандартну медикаментозну терапію, а саме нітрати, бета-блокатори, антагоністи кальцію, інгібітори АПФ ферменту, дезагреганти, діуретики, гіполіпідемічні препарати і комплекс санаторно-курортної реабілітації. Пацієнти першої групи (17 осіб) надійшли на реабілітацію через 7 діб після оперативного втручання при відсутності післяопераційних ускладнень і тяжких супутніх захворювань. Протипоказанням для раннього переведення в спеціалізоване відділення реабілітації були часті і тривалі напади стенокардії напруги і спокою, нестабільна стенокардія; свіжий інфаркт міокарда; недостатність кровообігу IV ф. кл. NYHA; виражені порушення ритму; виражена артеріальна гіпертензія з ураженням внутрішніх органів, що погано піддається корекції; післяопераційні ускладнення; наявність супутніх захворювань, що супроводжуються ли- хоманкою; залишкові явища тромбоемболії в судинах головного мозку. Пацієнти другої групи (48 осіб) надходили на реабілітацію через 1-2 місяці після операції. Алгоритм дослідження (до і після лікування) включав збір анамнезу, динамічне клінічне спостереження за об'єктивним і суб'єктивним станом пацієнтів, лабораторну діагностику (біохімічний аналіз крові, ліпідограма, цукор крові, інсулін, індекс НОМА, лептин) та інструментальні методи і дослідження (ЕКГ, УЗД серця, холтерівське моніторування ЕКГ, вимірювання артеріального тиску, частоти серцевих скорочень, шестихвилинний тест (ТШХ)). Для оцінки психологічного стану використовували шкалу HADS i шкалу тривожності Спілбергера, якість життя оцінювали за шкалою SF-36.

Результати й обговорення. При надходженні на реабілітацію в різні терміни після ХРМ ми виявили скарги різного характеру, а саме: в першій групі у 20,0 \% пацієнтів вони були пов'язані з недавнім оперативним втручанням, що можна виділити в постперикардіотомічний синдром, у 35,2 \% пацієнтів другої групи скарги були переважно пов'язані з порушенням психоемоційного стану, що відповідає кардіофобічному синдрому. Це підтверджувалося і дослідженнями психологічного статусу хворих. Так, у пацієнтів першої групи ми відзначали поліпшення психологічного статусу, пов'язане зі зменшенням переживань в зв'язку з очікуванням операції. Крім цього, згідно з результатами тесту Спілбергера показник реактивної тривожності у другій групі був на 12,6\% вищим, ніж у першій (табл. 1).

Таблиця 1. Показники тривоги та депресії у пацієнтів з IXC після хірургічної реваскуляризації міокарда залежно від терміну надходження на реабілітацію

\begin{tabular}{|l|c|c|c|c|}
\hline \multirow{2}{*}{\multicolumn{1}{|c|}{ Показники }} & \multicolumn{2}{c|}{ Група 1 $(\mathrm{n}=17)$} & \multicolumn{2}{c|}{ Група 2 ( $\mathrm{n=48)}$} \\
\cline { 2 - 5 } & без порушення & субклінічні порушення & без порушення & субклінічні порушення \\
\hline Шкала тривоги HADS & $4,3 \pm 1,1$ & $8,1 \pm 0,7$ & $5,8 \pm 1,8^{*}$ & $10,5 \pm 1,5^{*}$ \\
\hline Шкала депресії HADS & $4,8 \pm 1,0$ & $10,1 \pm 1,4$ & $6,1 \pm 1,2^{*}$ & $12,3 \pm 1,1^{*}$ \\
\hline $\begin{array}{l}\text { Реактивна тривожність } \\
\text { (опитувальник Спілбергера) }\end{array}$ & \multicolumn{2}{|c|}{$44,9 \%$} & & $57,5 \% *$ \\
\hline
\end{tabular}

Примітка: вірогідність відмінності показників між групами, $\mathrm{p} \leq 0,05$.

За даними опитувальника HADS у 43,9 \% пацієнтів першої групи та у 53,5 \% пацієнтів другої групи було виявлено субклінічні тривожно-депресивні розлади. Рівень тривоги у пацієнтів другої групи був вищий на 29,6 \% та рівень депресії - на 21,8\%. Окрім того, при оцінці за шкалою Спілбергера у пацієнтів другої групи реактивна тривожність була на $28,1 \%$ вищою. Аналіз даних говорить про необхідність ранньої реабілітації та застосування програм корекції нервово-психічного стану.

Сумарний показник якості життя у пацієнтів обох груп ілюструє задоволеність хворих цієї групи рівнем фізичного і психічного благополуччя, що пов'язано з безпосереднім впливом оперативного втручання. Але, як видно на рисунку 1, показники рольового функціонування залишаються низькими, причому у пацієнтів другої групи нижчі $(p \leq 0,05)$. Зниження цього показника свідчить про те, що повсякденна діяльність цих пацієнтів значно обмежена фізичним станом. Окрім того, низький показник психічного здоров'я в обох групах свідчить про наявність депресивних, тривожних переживань, психічне неблагополуччя. 


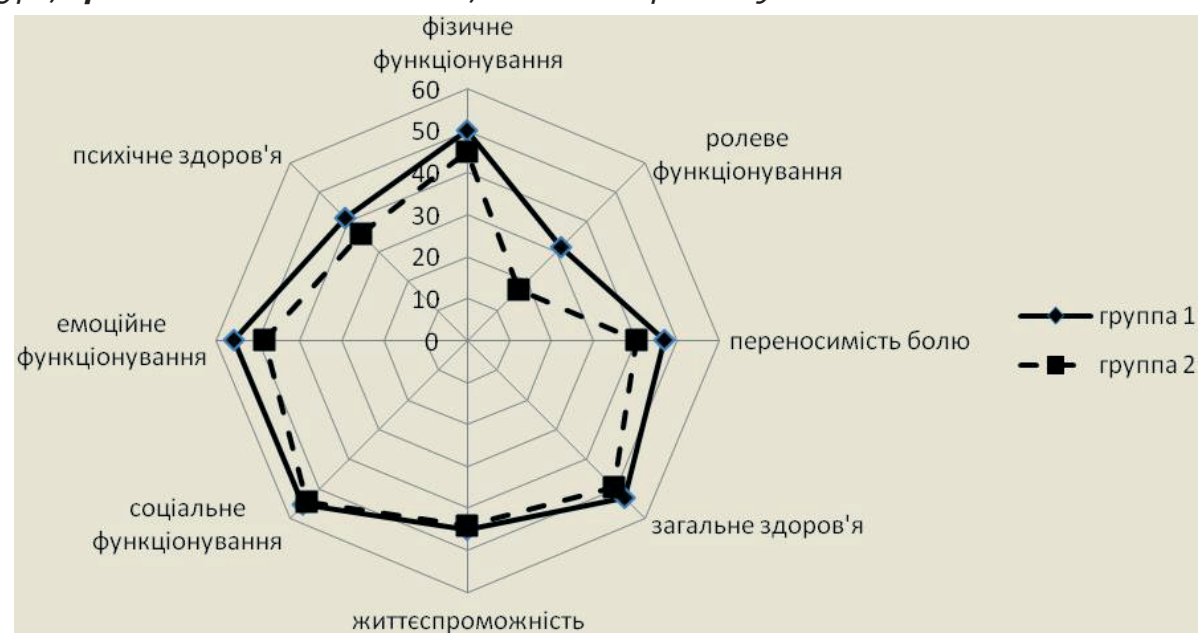

Рис. 1. Показники якості життя за опитувальником SF-36 у хворих на IXC після хірургічної реваскуляризації міокада в залежності від терміну надходження на реабілітацію.

Висновки. У пацієнтів з IXC після хірургічної реваскуляризації міокарда наявні явища психічної дезадаптації, причому більш виражені у паці$\epsilon$ нтів, які надходять на реабілітацію пізніше (через 1 місяць після АКШ), які не отримували відповідні ранні реабілітаційні заходи, що значно знижує якість життя цих пацієнтів.

Ранній початок реабілітації дозволить закріпити ефект хірургічного та медикаментозного лі-

\section{ЛІТЕРАТУРА}

1. Группы высокого риска смертности от болезней системы кровообращения у лиц с артериальной гипертензией (по данным десятилетнего когортного исследования) / В. П. Подпалов // Кардиология в Беларуси. 2011. - № 4. - С. 75-85.

2. Лутай М. И. Ведение больных с ишемической болезнью сердца и сопутствующей артериальной гипертензией в Украине. Результаты исследования ПРЕСТИЖ / М. И. Лутай // Український кардіологічний журнал. 2011. - № 1. - С. 25-36.

3. Марченко О. К. Фізична реабілітація осіб із ішемічною хворобою серця з синдромом інсулінорезистентності / О. К. Марченко, І. Н. Євстратова, М. Алшбул // Теорія та методика фізичного виховання і спорту. 2012. - № 1. - C. 77-80.

\section{REFERENCES}

1. Podpalov, V.P. (2011), Gruppy vysokogo riska smertnosti ot bolezney sistemy krovoobrashcheniya u lits s arterialnoy gipertenziyey (po dannym desyatiletnego kogortnogo issledovaniya) [Groups of high risk of mortality from diseases of the circulatory system in individuals with hypertension (according to the data of a ten-year cohort study)]. Kardiologiya v Belarusi - Cardiology in Belarus, (4), 75-85 [in Belarusian].

2. Lutay, M.I. (2011). Vedeniye bolnykh s ishemicheskoy boleznyu serdtsa i soputstvuyushchey arterialnoy кування, отриманого на стаціонарному етапі, адаптувати хворого до майбутніх побутових навантажень, соціального спілкування, трудової діяльності.

Перспективи подальших досліджень полягають у розробці програм ранньої реабілітації хворих з IXC після перенесеної ХРМ з урахуванням необхідності корекції психологічного стану.

4. Оганов Р. Г. Профилактическая кардиология: надежды и реальность / Р. Г. Оганов // Здравоохранение. - 2012. - № 9. - С. 60-67.

5. Johnson T. J. Depression predicts repeated heart failure hospitalizations / T. J. Johnson// J. Card. Fail. 2012. - № 18(3). - P. 246-252.

6. ESC Guidelines on myocardial revascularization // Eur. Heart J. - 2010. - Vol. 31. - P. 2501-2555.

7. Salim Yusuf. Deciphering the causes of cardiovascular and other complex diseases in populations: achievements, challenges, opportunities, and approaches / Yusuf Salim, Anand Sonia // Progress in Cardiovascular Diseases. 2010. - Vol. 53, № 1. - P. 62-67.

8. Shutt A. The role of physical activity in secondary prevention of coronary heart disease // A. Shutt, E. V. Bolotova, M. Xale // Cardiology. - 2005. - Vol. 7. - P. 83-86.

gipertenziyey v Ukraine. Rezultaty issledovaniya PRESTIZH [Management of patients with coronary heart disease and concomitant arterial hypertension in Ukraine. Results of the research PRESTIGE]. Ukrainskyi kardiolohichnyi zhurnal-Ukrainian Cardiological Journal, 1, 25-36 [in Ukainian].

3. Marchenko, O.K., Yevstratova, I.N. \& Alshbul, M. (2012). Fizychna reabilitatsiia osib iz ishemichnoiu khvoroboiu sertsia z syndromom insulinorezystentnosti [Physical rehabilitation of persons with ischemic heart disease with insulin resistance syndrome]. Teoriya ta metodyka fizych- 
Огляди літератури, оригінальні дослідження, погляд на проблему

noho vykhovannia i sportu - The Theory and Methods of Physical Education and Sport, (1), 77-80 [in Ukrainian].

4. Oganov, R.G. (2012). Profilakticheskaya kardiologiya: nadezhdy i realnost [Preventive cardiology: hopes and reality]. Zdravookhraneniye - Public Health, (9), 60-67 [in Russian].

5. Johnson, T.J. (2012). Depression predicts repeated heart failure hospitalizations. J. Card. Fail, 18 (3), 246-252.

6. European society of cardiology. (2010). Guidelines on myocardial revascularization. European Heart Journal, $31,2501-2555$.
7. Salim, Yusuf \& Anand, Sonia. (2010). Deciphering the causes of cardiovascular and other complex diseases in populations: achievements, challenges, opportunities, and approaches. Progress in Cardiovascular Diseases, 53 (1), 62-67.

8. Shutt, A., Bolotova, E.V. \& Xale, M. (2005). The role of physical activity in secondary prevention of coronary heart disease. Cardiology, 7, 83-86.

\title{
ОСОБЕННОСТИ ПСИХОЛОГИЧЕСКИХ РАССТРОЙСТВ У БОЛЬНЫХ ИШЕМИЧЕСКОЙ БОЛЕЗНЬЮ СЕРДЦА ПОСЛЕ ХИРУРГИЧЕСКОЙ РЕВАСКУЛЯРИЗАЦИИ МИОКАРДА НА РАЗНЫХ ЭТАПАХ РЕАБИЛИТАЦИИ
}

\author{
ГУ «Украинский научно-исследовательский институт медицинской реабилитачии и курортологии \\ МЗ Украины»
}

РЕЗЮМЕ. Статья посвящена изучению особенностей психологического состояния больных ишемической болезнью сердца после хирургической реваскуляризации миокарда в зависимости от сроков поступления на реабилитацию.

Материал и методы. Было обследовано 65 пациентов после аортокоронарного шунтирования (АКШ) (17 пациентов через 7 суток после оперативного вмешательства и 48 - через 1-2 месяца). Для оценки психологического состояния использовали шкалу HADS и шкалу тревожности Спилбергера, качество жизни оценивали по шкале SF-36.

Результаты. Выявлено достоверное снижение качества жизни у пациентов, которые поступали на реабилитацию через 1-2 месяца и не получали раннего восстановительного лечения. При оценке тревоги и депрессии по шкале HADS были обнаружены субклинические тревожно-депрессивные расстройства у 43,9 \% пациентов при раннем поступлении на реабилитацию и у 53,5 \% - при позднем. Снижение качества жизни за счет ролевого функционирования более выразительным было у пациентов, не получавших ранней реабилитации ( $\leq \leq 0,05)$.

КЛючЕВЫЕ СЛОВА: ишемическая болезнь сердца; хирургическая реваскуляризация миокарда; этапная реабилитация; качество жизни; психологические расстройства.

\section{FEATURES OF PSYCHOLOGICAL DISORDERS IN PATIENTS WITH ISCHEMIC HEART DISEASE AFTER SURGICAL REVASCULARIZATION OF MYOCARDIAL IN DIFFERENT STAGES OF REHABILITATION}

@O. V. Kolodenko

Ukrainian Research Institute of Medical Rehabilitation and Resorts of the Ministry of Health of Ukraine

SUMMARY. The article is devoted to the study of the psychological state of patients with coronary heart disease after myocardium surgical revascularization at various stages of rehabilitation.

Materials and Methods. A total of 65 patients after coronary artery bypass graft were examined (17 patients 7 days after surgery and 48 after 1-2 months). To assess the psychological state, the HADS scale and the Spielberger anxiety scale were used, and the quality of life was assessed on a scale of SF-36.

Results. A possible decrease in the quality of life was found in patients who received rehabilitation after 1-2 months and did not receive early rehabilitation. In the assessment of anxiety and depression in the HADS scale, subclinical anxiety and depression was detected in $43.9 \%$ of patients with early onset rehabilitation and $53.5 \%$ - at late. Lowering the quality of life due to role-playing function was more pronounced for patients who did not receive early rehabilitation $(p \leq 0.05)$.

KEY WORDS: ischemic heart disease; myocardium surgical revascularization; stage rehabilitation; quality of life; psychological disorders. 